\title{
Recenzja książki Miejsce geopolityki w polskiej myśli politycznej XIX i XX wieku Rafała Juchnow- skiego, Wydawnictwo Adam Marszałek, Toruń 2018, ISBN: 978-83-8019-918-7, ss. 576
}

Książka Rafała Juchnowskiego pod tytułem Miejsce geopolityki w polskiej myśli politycznej XIX i XX wieku jest niezwykle interesującym oraz wartościowym głosem w dyskusji na temat nie tyle znaczenia samej geopolityki, co jej postrzegania, rozumienia oraz operacjonalizowania przez polskich myślicieli. Tytułowa „polska myśl polityczna” była istotnym budulcem kształtowania zarówno polityki zagranicznej państwa, jak i krajowej polityki społeczno-politycznej. Wszystko to z kolei przekładało się na ewoluującą pozycję kraju w środowisku międzynarodowym, dlatego najważniejszym zagadnieniem, wokół którego autor budował swój wywód, było pytanie o wpływ, jaki na polską myśl polityczną miały idea mocarstwowości oraz rozbiory (a więc stan głębokiej i paraliżującej zależności). Autor już na wstępie stawia tezę, że zasadami polskiej geopolityki w ciągu wieków było dążenie (obok uzyskania mocarstwowego statusu państwa) do zaprowadzenia federalnego porządku w Europie Środkowo-Wschodniej.

W procesie operacjonalizacji problemu badawczego niewątpliwie kluczowe znaczenie miało stworzenie i konsekwentne wykorzystanie modelu eksplanacyjnego, opartego na założeniach metodologicznych konstruktywizmu, a co za tym idzie - na wynikającym z tego teoretycznego podejścia sposobie ujmowania procesów i struktur społeczno-politycznych. Adaptacja teorii konstruktywistycznej do analizy i wyjaśniania znaczenia geopolityki w kształtowaniu się polskiego myślenia mocarstwowego była możliwa dzięki świadomemu sięgnięciu do dorobku szkoły „Annales” jako narzędzia umożliwiającego badanie zmian ideowych — ich przyczyn, przebiegu i konsekwencji. Tak skonstruowane ramy teoretyczne wykorzystano do zbadania ewolucji polskiej myśli politycznej w ciągu wieków. Tymczasem przyjęty model skutecznie realizował funkcję integracyjną, zapewniając koherencję między empirią a teorią; innymi słowy — wnioski teoretyczne głęboko zakorzenione były w solidnie przeprowadzonej analizie rzeczywistości z uwzględnieniem jej złożoności i dynamizmu. Trzeba odnotować, że argumentacja zaprezentowana w książce odznaczała się spójnością i konsekwencją. 
Wartością dodaną książki jest spojrzenie na dyskurs geopolityczny nie tylko z perspektywy terytorialno-politycznej, lecz także - co szczególnie cenne - z perspektywy kulturowo-tożsamościowej. Autorowi udało sie w przekonujący sposób dokonać swoistej syntezy perspektyw. Zabieg ten pozwolił rzucić światło interpretacyjne na analizowany $\mathrm{w}$ książce problem terytorialności państw $\mathrm{z}$ uwzględnieniem kontekstów społecznych, politycznych, gospodarczych i kulturowych, charakterystycznych dla danej epoki i wyzwań z nią związanych. Takie kompleksowe ujęcie w zestawieniu z bogactwem treści merytorycznych i szczegółowych analiz umożliwiło R. Juchnowskiemu sformułowanie spójnych ocen założeń polskiej myśli geopolitycznej oraz implikacji ich mizerii względnie nieadekwatności w konkretnych cyklach historycznych.

Autor dokonał bardzo silnie osadzonego w literaturze przedmiotu procesu definiowania kluczowych pojęć, dostrzegając wyzwania oraz zagrożenia wynikające ze swoistego chaosu w zakresie, jaki daje o sobie znać nie tylko na gruncie debat akademickich, lecz także tych toczących się paralelnie w publicystyce, również za pośrednictwem mediów. W autorskim katalogu najważniejszych pojęć są i te, które autor opisuje i wyjaśnia (w tym chociażby geopolityka, polska myśl polityczna, Europa Środkowo-Wschodnia oraz te, dzięki którym wyjaśnia między innymi: mocarstwo i mocarstwowość, suwerenność, federalizm).

Lektura książki R. Juchnowskiego dla odbiorcy przyzwyczajonego do obrazów, przestrzennych zestawień i streszczeń jest jednak pewnym wyzwaniem. Dotyczy to płaszczyzny percepcyjno-kognitywnej, ale także odnosi się do możliwości wejścia czytelnika w krytyczny dialog z treściami książki czy wręcz w polemikę. Styl narracji jest wymagający, nie pozwala $\mathrm{w}$ zasadzie na lekturę jedynie fragmentów. Struktura wewnętrzna, choć prosta, skłania do skupienia się na lekturze obszernych części. Książka składa się z trzech rozdziałów, rozbudowanego i wielowątkowego wstępu oraz bardzo dobrze napisanego, syntetycznego zakończenia. Na każdy $\mathrm{z}$ rozdziałów składają się trzy obszerne podrozdziały. $\mathrm{W}$ rozdziale pierwszym znalazły się rozważania metodologiczne i definicyjne, w tym konceptualizacja kluczowych dla rozprawy pojęć. Przeanalizowane zostały także związki między pojęciami. Autor z sukcesem podjął wyzwanie, jakie wynika z procesu ewolucji znaczeń pojęć $\mathrm{w}$ toku historycznych przemian społeczno-polityczno-gospodarczo-kulturowych. Dotyczy to szczególnie sposobu definiowania kategorii „Europa Środkowo-Wschodnia”. Ostatnim wyróżnionym zagadnieniem w tym rozdziale było wskazanie oraz scharakteryzowanie determinant i uwarunkowań polskiej geopolityki. W rozdziale drugim i trzecim autor pochyla się nad dwoma, niejako alternatywnymi konstruktami (federacją i konfederacją), na podstawie których Polska miała (z różnym skutkiem) budować swoją mocarstwową pozycję. Rozdział drugi jest jakby spojrzeniem do wewnątrz, pogłębioną refleksją nad ewoluującą koncepcją mocarstwowości w świetle idei piastowsko-jagiellońskiej. Niezwykle ciekawe poznawczo i intelektualnie inspirujące są $\mathrm{w}$ tym rozdziale dywagacje autora na temat politycznego i gospodarczego znaczenia mórz (Bałtyku, Morza 
Czarnego, Adriatyku), pozwalające na lepsze zrozumienie koncepcyjnych wysiłków rozmaitych środowisk intelektualnych i politycznych w czasach minionych, ale i współczesnych. W rozdziale trzecim natomiast podkreślone zostaje znaczenie kontekstów polityczno-międzynarodowych z uwzględnieniem dynamiki multilateralnej. Autorowi udało się tutaj wykazać znaczenie relacji międzynarodowych na rzecz realizacji strategii mocarstwowości. „Współzależność”, a czasami głęboką i pozornie paraliżującą „zależność” trafnie potraktował on jako funkcję korelacji między intersubiektywnymi ambicjami, motywacjami a posiadanymi, rzeczywistymi zasobami.

Autor nie zdecydował się na dalej idącą strukturyzację, w tym zastosowanie śródtytułów w obrębie podrozdziałów. Zapewne mogłyby one nawigować czytelnika, szczególnie tego, który zechciałby raczej zapoznać się z fragmentami ponad pięciuset stronnicowej rozprawy. Niestety, w przypadku tej konkretnej pozycji nie jest dobrym pomysłem zapoznawanie się z „wyjątkami” z książki. Wysiłek czytelnika podejmującego się lektury zgodnie z intencją autora - nie selektywnej, a systematycznej i całościowej — zostanie z pewnością nagrodzony. Książkę się po prostu „czyta”, stopniowo zagłębiając się w interesującą i autorską linię argumentacji. Nie jest ona zatem wyłącznie kompendium wiedzy (choć zważywszy na ilość zabranych informacji oraz analiz również może taką funkcję realizować), ale nade wszystko jest ważnym punktem referencyjnym na mapie nie tylko polskiej, lecz także europejskiej myśli politycznej.

Pytania oraz krytyczne refleksje rodzące się w trakcie lektury wielokrotnie tracą rację bytu po przeczytaniu kolejnych fragmentów. Należy przyznać, że jest to ciekawe ujęcie, gdy autor stawia nie tyleż pytania badawcze, co staje w obliczu koncepcyjnych i interpretacyjnych dylematów; co więcej - stawia im czoła. Badanym problemom natomiast przygląda się z „,różnych stron”, weryfikuje, a czasami falsyfikuje powszechnie przyjęte twierdzenia i tezy. Jednocześnie wspomaga się dobrym warsztatem i stawia nowe tezy o charakterze problemowym oraz formułuje własne oceny - zarówno o charakterze praktyczno-empirycznym, jak i bardzo cenne generalizacje natury teoretycznej.

R. Juchnowski, konstruując swoją opowieść o polskiej myśli geopolitycznej, nie wpadł w pułapkę „chronologizmu”. Odejście od analizy linearnej, uwzględniającej porządek czasu bardziej niż przestrzeni, pozwoliło mu na swoiste podróże w czasie i przestrzeni, gdzie czasem autor poruszał się zgodnie z wektorami horyzontalny$\mathrm{mi}$, a czasem wertykalnymi. W rezultacie otrzymujemy obrazy wielowymiarowe, wielowątkowe, lecz ważne, spójne.

Książka powstała na podstawie bardzo bogatej bazy źródłowej. Wszechstronna kwerenda archiwalna pozwoliła na wykorzystanie w pracy często nieopracowanych wcześniej materiałów pochodzących z Archiwum Akt Nowych w Warszawie, zespołu Ministerstwa Prac Kongresowych, Zakładu Narodowego imienia Ossolińskich, Bibliotek: Narodowej i Uniwersyteckiej w Warszawie, Biblioteki Polskiej w Polskim Ośrodku Społeczno-Kulturalnym w Londynie oraz Studium Polski 
Podziemnej w Wielkiej Brytanii, Archiwum Instytutu Polskiego i Muzeum imienia generała Sikorskiego. Zebranie, opracowanie i analiza jakże cennego materiału źródłowego pozwoliło na interpretację polskich założeń doktrynalnych dotyczących geopolityki. Dodatkowo w pracy dokonano bardzo obszernego i wnikliwego przeglądu oraz analizy literatury zastanej.

Podsumowując, recenzowana książka zasługuje na polecenie szerokiemu gronu potencjalnych odbiorców. Zważywszy na to, że zawiera ona wiele doskonale opracowanych informacji oraz wiele dobrze przeprowadzonych analiz, powinna być lekturą obowiązkową dla studentów, badaczy, ale też środowisk eksperckich, publicystów i - co ważne - polityków.

Joanna Dyduch ORCID: 0000-0003-4879-5079

Uniwersytet Jagielloński Żywiec, 18.05.2020 r. 